Article

\title{
Endemism of Uropodina Mites: Spurious or Real?
}

\author{
Jerzy Błoszyk ${ }^{1,2}$ and Agnieszka Napierała ${ }^{1, *(\mathbb{D})}$ \\ 1 Department of General Zoology, Faculty of Biology, Adam Mickiewicz University, ul. Uniwersytetu \\ Poznańskiego 6, 61-614 Poznań, Poland; bloszyk@gmail.com \\ 2 Natural History Collections, Faculty of Biology, Adam Mickiewicz University, ul. Uniwersytetu \\ Poznańskiego 6, 61-614 Poznań, Poland \\ * Correspondence: agan@amu.edu.pl
}

Received: 23 June 2020; Accepted: 14 July 2020; Published: 18 July 2020

\begin{abstract}
Analyzing the data from the existing literature about geographic distribution of mites from the suborder Uropodina (Acari: Mesostigmata), one can get the impression that this group of mites is characterized by an unusual extent of endemism on a global scale. This observation encouraged the authors of this study to ascertain whether endemism in Uropodina mites is a real feature of this group or whether it stems from the current state of affairs in this field of research. The study is based on evidence from the literature on the topic and data obtained from long-term research conducted on extensive materials from all over the globe (over 40,000 samples). The discussion presented in the article is supported by many examples, showing that both hypotheses can in fact be proved right. The major point of reference in this study is the fairly well-known fauna of Uropodina in Europe, whereas South America is the testing area for the two hypotheses.
\end{abstract}

Keywords: Acari; biogeography; geographical variability; Mesostigmata; neotropical region; palearctic species; range of occurrence; Rotundabaloghia; species identification; Uropoda (Phaulodinychus) penicillata

\section{Introduction}

Mites from the suborder Uropodina (Acari: Mesostigmata) are quite characteristic and easy to distinguish from other species of mites. Due to their large body size and high form diversity, these arachnids have been the object of research interests of many acarologists for a long time. The first descriptions of species were written over 240 years ago [1], and most of them were described at least 100 years ago.

As for now, over 2000 species from different geographical locations of the whole globe have already been classified as Uropodina and described in various studies [2]. However, many of the described species were found only in one location. The fact is that despite considerable dispersion abilities of these mites (phoresy), most Uropodina species have a restricted range of occurrence [2-5]. Most research in this field conducted so far has focused on the fauna of Europe, especially on Central Europe, where in some countries the distribution of particular species has been thoroughly described in numerous studies. Among such countries, there are Poland and Slovakia, where the ranges of Uropodina species were analyzed by means of the Universal Transverse Mercator (UTM) grid [3,5-8] or a different grid system (e.g., the grid system of Databank of the Fauna of Slovakia) [4]. Furthermore, the eastern states of Australia have also been recently thoroughly examined in this respect [9-12]. Nevertheless, little is still known about the exact distribution of Uropodina mites in other parts of the globe, where researchers usually describe only random occurrences of the species they describe, which in turn may suggest immense endemism in this group of organisms.

The authors of the current article present their own observations concerning the zoogeography of this group of mites on the basis of long-term research and materials obtained from all over the 
globe. The major aim of this study is therefore to verify the hypothesis that the endemism of species from suborder Uropodina implied by the data available in the existing literature on the topic is in fact spurious.

\section{Materials and Methods}

The material used in this study comprises over 40,000 samples (obtained mainly from sieved litter and soil, as well as from unsieved material from different types of unstable microhabitats such as dead wood, nests of birds and small mammals, anthills, etc.) collected in different parts of the globe by different collectors, in the period 1941-2019. All samples were sorted out, and the extracted mites were identified by the first author or coworkers. The obtained samples contained over 300,000 specimens of mites from the suborder Uropodina. The core of the material analyzed for the purpose of this study contained samples from Europe (mainly from Poland-30,000 samples), and also from Spain (30 samples), France (50 samples), Belgium (40 samples), the Netherlands (100 samples), Germany (50 samples), Denmark (100 samples), Sweden (30 samples), Norway (500 samples), the Czech Republic (150 samples), Slovakia (170 samples), and the Ukraine (30 samples). The extensive materials of exotic species from all continents, which in the past were used mainly to describe new species, in this study were analyzed to ascertain the geographical distribution of particular species. These materials allowed us to put forward the hypothesis about the "spurious endemism" of Uropodina mites all over the globe: in Australia and Tasmania (700 samples), New Guinea (50 samples), New Zealand (30 samples), South America (300 samples), Africa (100 samples), Madagascar (30 smples), India (80 samples), Nepal (50 samples); Indonesia (20 samples), Thailand (10 samples), Vietnam (20 samples), Mongolia (10 samples), Russia (Syberia—50 samples), Afganistan (20 samples), and Pakistan (5 samples).

The whole material used in this study has been deposited in The Invertebrate Databank, (Natural History Collections, Faculty of Biology AMU, Poznań, Poland). The obtained metadata are also available through the on-line platform developed within the digital project AMUNATCOLL: AMU Nature Collections on the Internet: Digitization and the biodiversity data resources of the Faculty of Biology at Adam Mickiewicz University in Poznań are available at https://rhus-76.man.poznan.pl:3000/.

\section{Results and Discussion}

\subsection{Geographical Ranges of Uropodina}

Interestingly, there are virtually no cosmopolitan species among Uropodina mites. Their range of occurrence is usually confined to one geographical region, and therefore, chiefly to one continent. One of the few exemptions in this respect are the palearctic species, which occur in Europe and Asia. The examples of such species are: Oodinychus ovalis (C.L.Koch, 1839), Trichouropoda patavina (G. Canestrini, 1885), T. polytricha (Vitzthum, 1923), Uroobovella marginata (C. L. Koch, 1829), Apionoseius infirmus Berlese, 1887 (in Europe and Kazakhstan); Dinychus perforatus Kramer, 1882, Oplitis paradoxa Berlese, 1919, Trachytes aegrota (C.L.Koch, 1841), T. patavina, T. tuberosa (Hirschmann et Zirngiebl-Nicol, 1961), A. infirmus, Uroseius acuminatus (C.L. Koch, 1847) (in Europe and Mongolia); U. hunzikeri Schweizer, 1922 (in Europe and Tajikistan); and Leiodinychus orbicularis (C. L. Koch, 1839) (in Europe and India). However, due to the fact that ranges of Uropodina mites have been determined to a different extent in each country on all continents, the available data are still fragmentary. Moreover, one cannot be certain whether the ranges of some Uropodina species, which are much broader than one might expect, are in fact results of incorrect identification of those species. For example, a quite common European species, T. aegrota, has also been found in the USA [2]. However, the lack of any comparative material in this case (museum collections are extremely helpful in such cases) prevents us from checking whether indeed it is the same species. This species could have been transported from Europe with ballast soil of sailing ships during the colonization period, when many cargo ships started regular trips from Europe to North America. This means that T. aegrota is probably an extraneous 
species in this geographical region, and it is also possible that the found specimens were incorrectly identified. In 1996, Błoszyk and Szymkowiak [13] described a species in Utah (T. kaliszewskii from Provo) which is very similar to T. aegrota. It is very likely that the species has a broader range of occurrence and was mistakenly identified as the European species T. aegrota. A similar situation has been observed when specimens of extraneous species were found in Polish seaports with warehouses containing wood from exotic trees [14-16].

In the area of Poland, some Uropodina species have their northern or western boundaries of occurrence range. Among the species with such ranges there are T. irenae (Pecina, 1970) and T. minima (Trägårdh, 1910) [17,18]. Trachytes irenae occurs only in the southern parts of Poland (Figure 1), and in Europe the range of occurrence of this species is also narrow (Figure 1A). A similar situation can be also observed in the case of T. minima (Figure 2). Moreover, T. montana (Willmann, 1953) [19] is a mountainous species, which in Europe usually occurs at the altitude over $1000 \mathrm{~m}$ a.s.l., and in Poland it also occurs only in the mountains in the southern parts of the country (Figure 3).
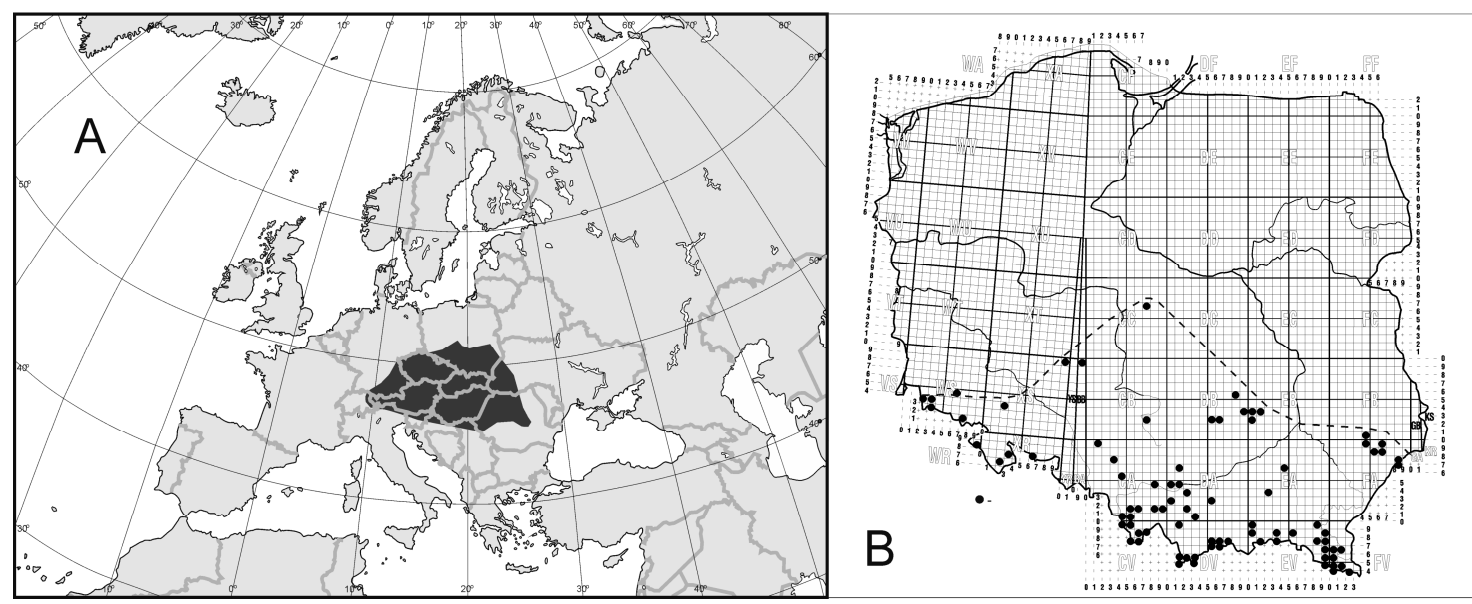

Figure 1. Range of Trachytes irenae: (A) in Europe, (B) in Poland; black dots-recorded occurrences of the species, dotted line-northern range boundary.
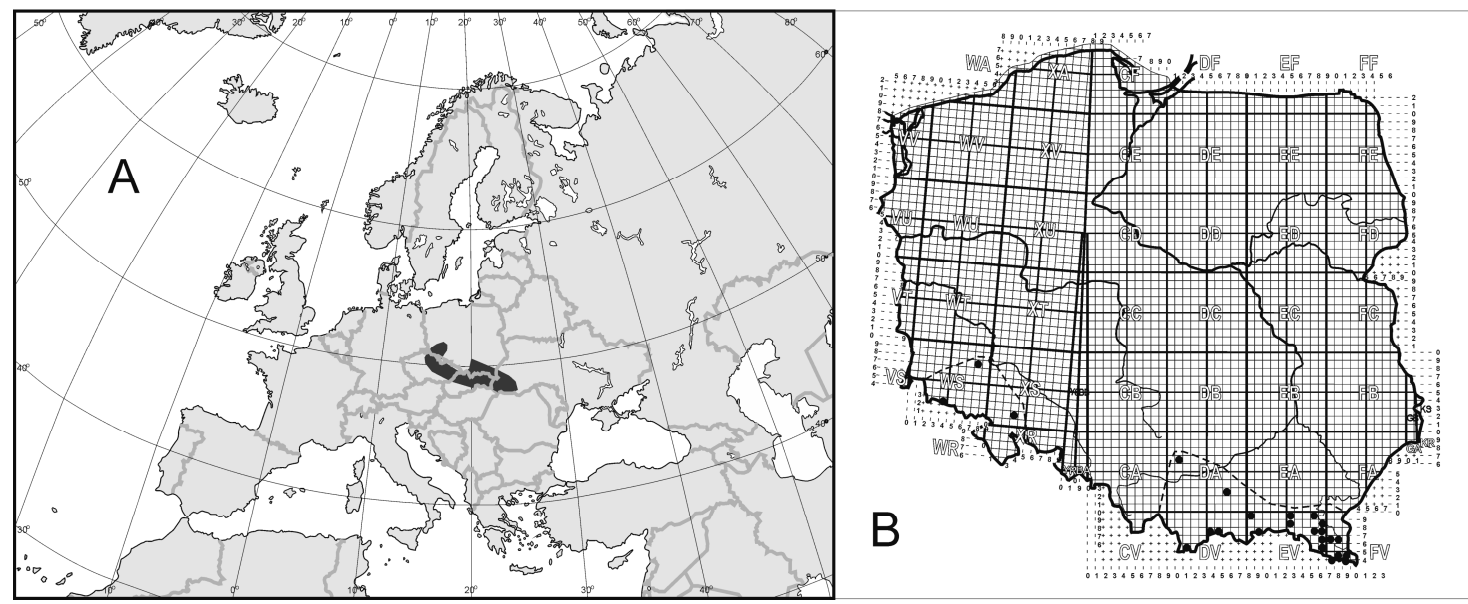

Figure 2. Range of Trachytes minima: (A) in Europe, (B) in Poland; black dots-recorded occurrences of the species, dotted line-northern range boundary. 

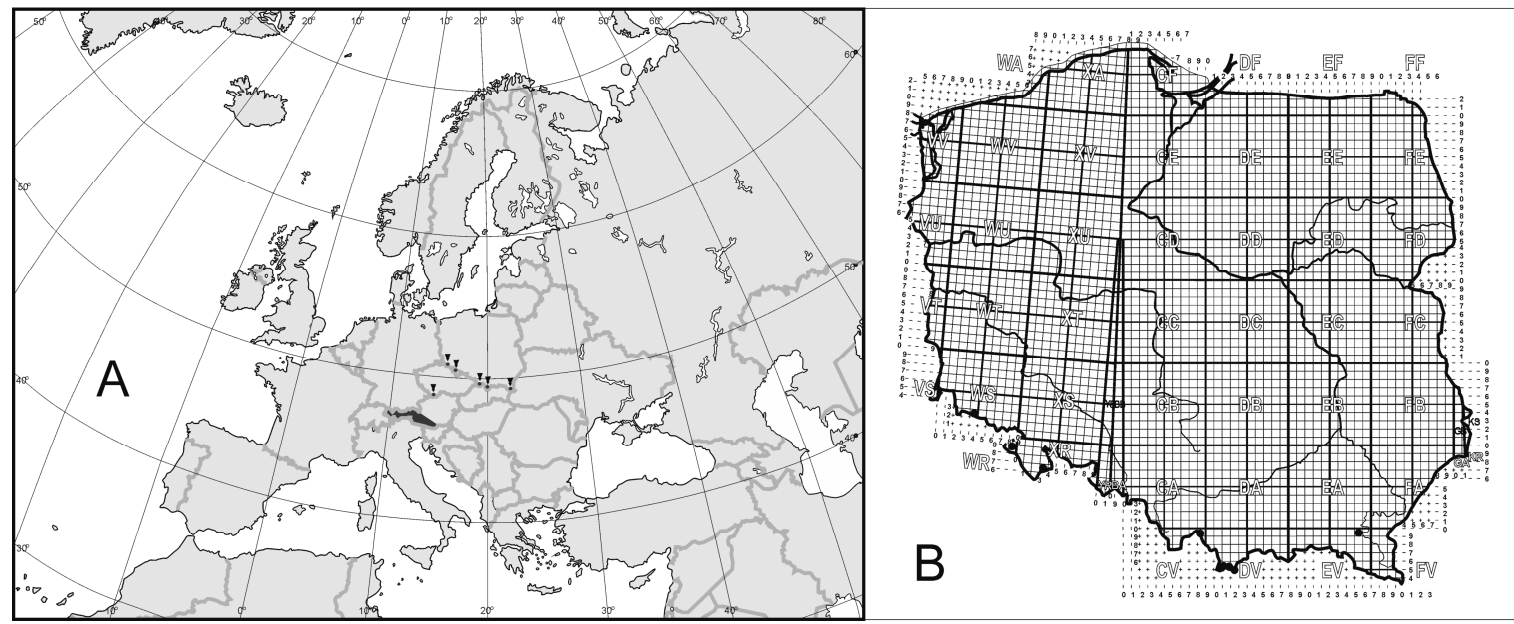

Figure 3. Range of Trachytes montana: (A) in Europe, (B) in Poland; black-recorded occurrences of the species.

The disjunctive range of occurrence is observed in the case of Neodiscopoma splendida Vitzthum, 1941. Southern and northern boundaries of range of occurrence of this species are separated by an area with no specimens of this species in the central part of Poland (Figure 4).
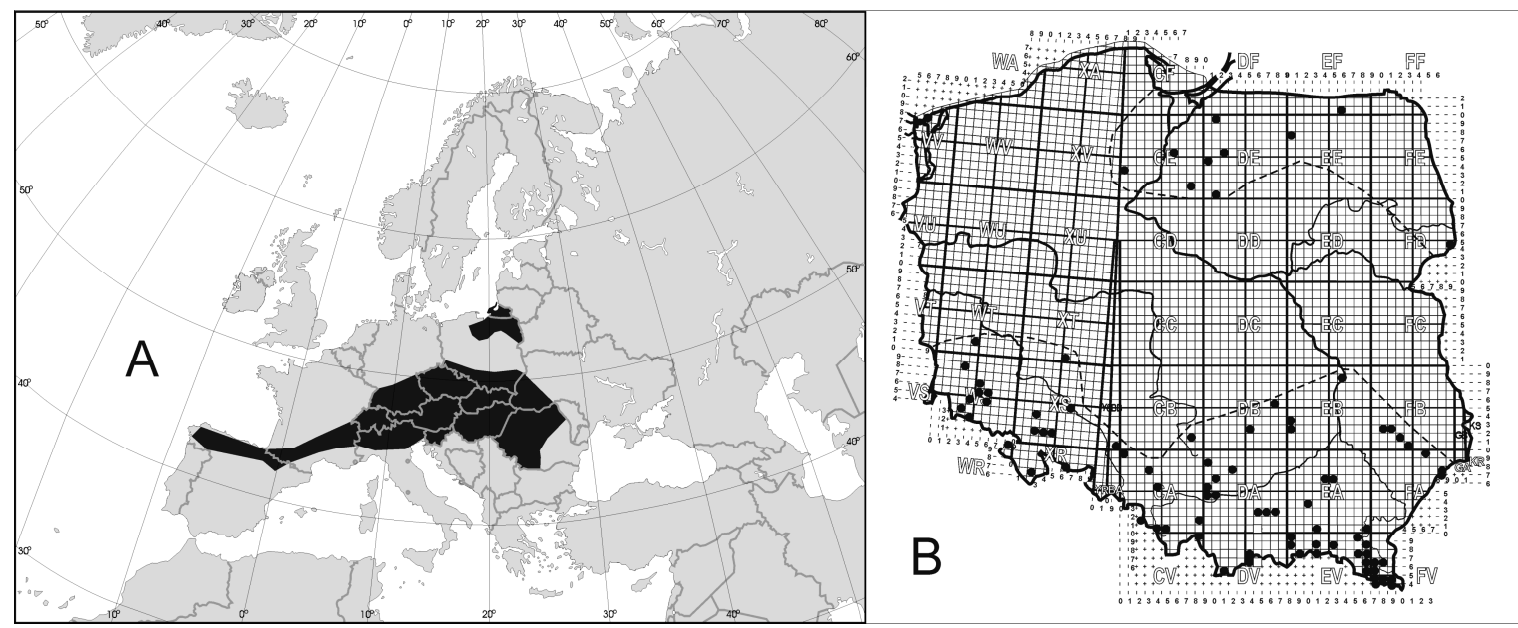

Figure 4. Range of Neodiscopoma splendida: (A) in Europe, (B) in Poland; black dots-recorded occurrences of the species, dotted line-occurrence range of southern and northern populations.

Among the species from the eastern Carpathians which occur in Poland, there are Trachytes splendida (Hutu, 1973), Urodiaspis stammeri (Hirschmann and Zirgiebl-Nicol, 1969) (Figure 5), and Cilliba selnicki (Hirschmann and Zirgiebl-Nicol, 1969) [3,4]. 

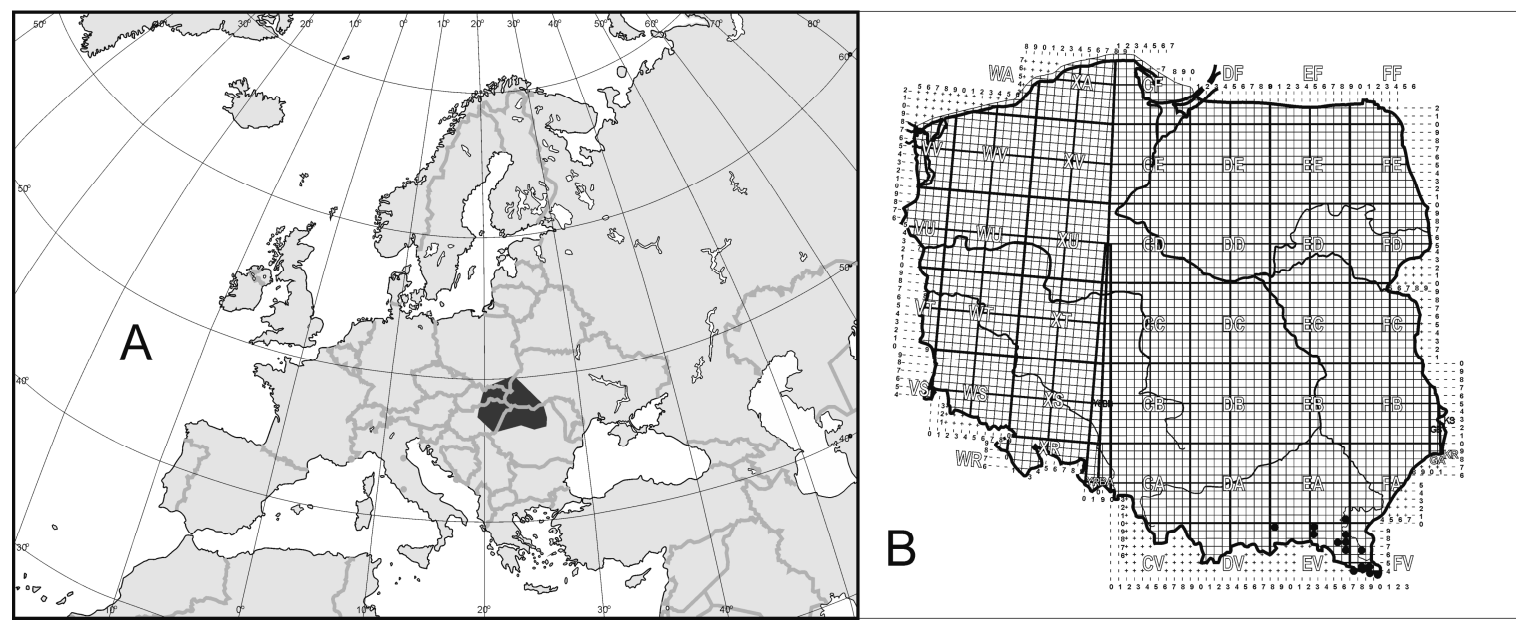

Figure 5. Range of Urodiaspis stammeri: (A) in Europe, (B) in Poland; black dots-recorded occurences of the species.

The so-called "Atlantic" species which occur in the area of Poland are such species as Cilliba erlangensis (Hirschmann, Zirngiebl-Nicol, 1969), Olodiscus misella (Berlese, 1916), and Polyaspinus cylindricus (Berlese, 1916), which have their eastern range boundaries in this country (Figure 6). The ranges of occurrence of the abovementioned species are similar to that of the European beech-Fagus sylvatica L.

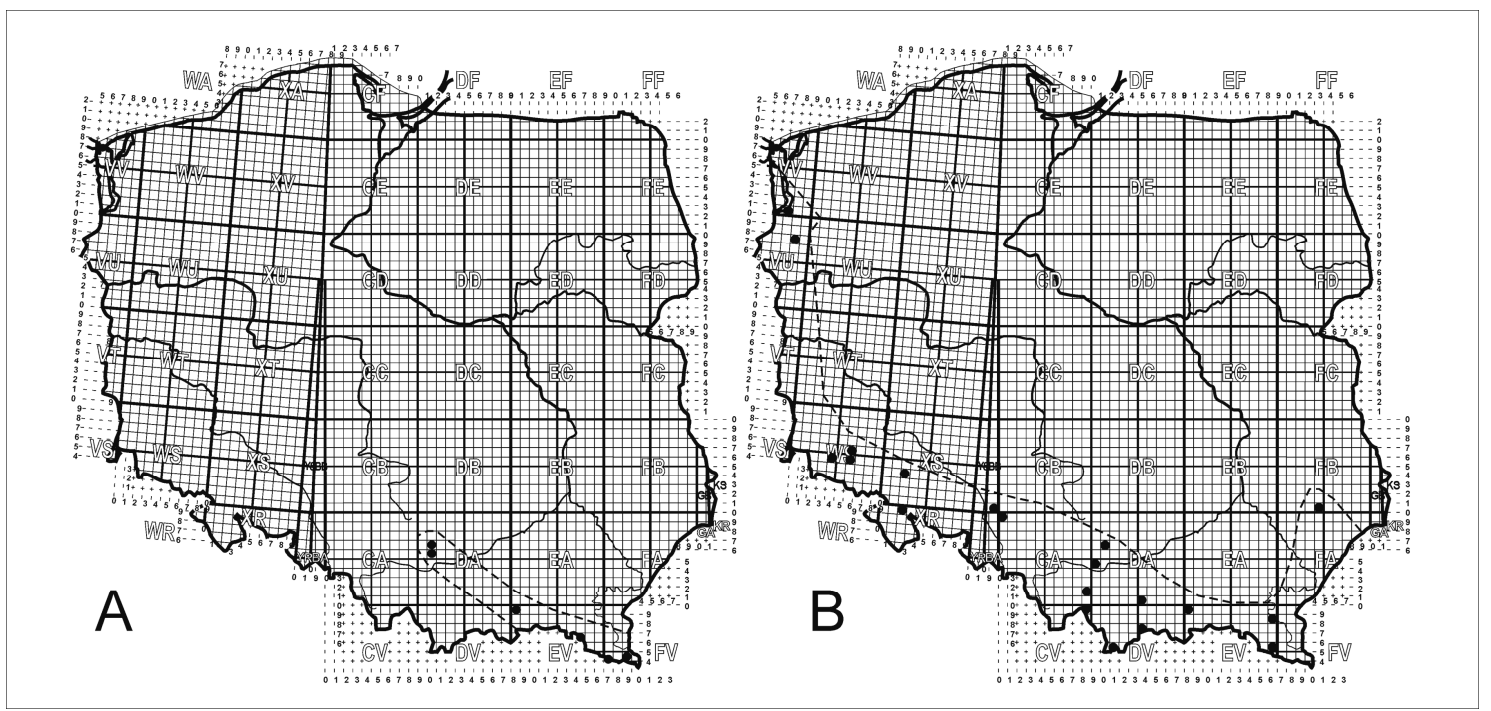

Figure 6. Species with their eastern range boundaries in Poland: (A) Olodiscus misella, (B) Cilliba erlangensis; black dots-recorded occurrences of the species.

The examples of range boundaries of selected Uropodina species in Poland and Europe adduced the above result from the geological history of this region (especially the Peistocene glaciations), and subsequently the habitat requirements of the species (including, for example, the range of tree species and type of the forest preferred by the mite species as habitats), as well as the dispersion abilities and reproduction strategy of the species (parthenogenesis vs. sexual reproduction). For this reason, it is very important to consider every discovery of a new species in a given area in a broader context, preferably in relation to the biology of the species and its associations with the environment. Recording occurrences of already described species in new locations is also very important, as this will allow us to determine more precisely their exact geographical distribution in the future. 
In this study, we also analyzed the range of occurrence of some Uropodina species from Australia. The results of the analyses show that particular genera within Uropodina form in each of the discerned types of rain forests found in Australia vicariants, which means that each type of forest has its own specific Uropodina species. A good example can be species from the genus Acroseius occurring in rainforests on the eastern coast. Every type of rainforest on this continent has its own specific species of Uropodina from this genus. Moreover, the ranges of these species overlap with the biogeographical boundaries of Australia (Figure 7) [10,11].

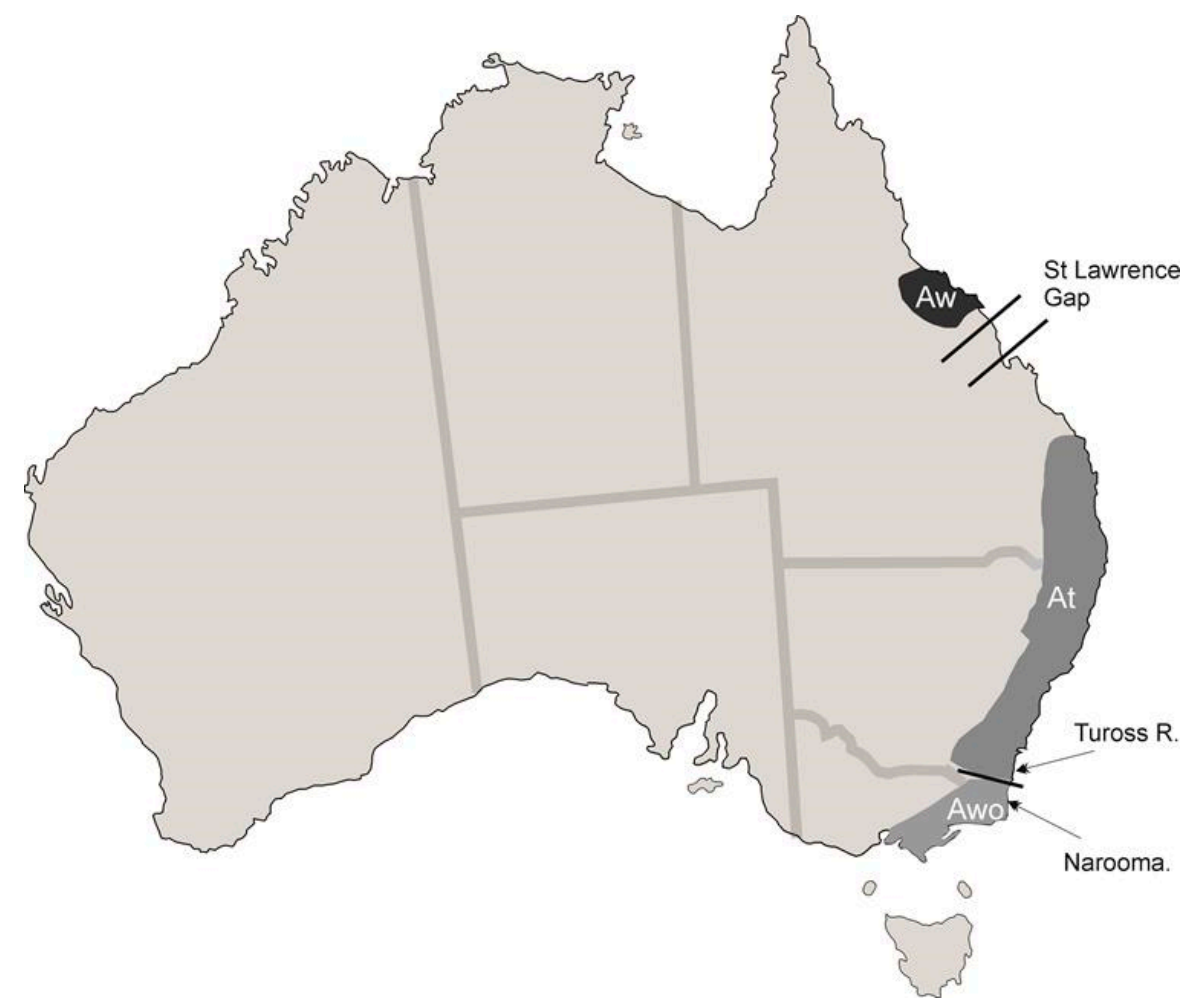

Figure 7. Distribution of species of Acroseius: Aw-A. weiri, At-A. tuberculatus, Awo-A. womersleyi against biogeographical boundaries of Australia (according to Błoszyk et al. 2013 [11], slightly changed).

For example, Acroseius weiri occurs only in an isolated area of a tropical rainforest in Eungella National Park, separated from more southerly areas of forest by the dry St. Lawrence Gap, which is also recognized as a biogeographic barrier for reptiles [20], glow-worms [21], and land snails [22]. The southern range boundary of $A$. tuberculatus (Clyde Mountain) is close to the northern range of A. womersleyi (Brown Mountain). The two species are separated there by the valley of the Tuross River, which does not appear to offer a significant biogeographic barrier. However, the rainforest in this area is confined to a series of very small scattered patches among the Eucalyptus forest, and there is a large gap in the distribution of these patches inland from Narooma [23], which coincides with the gap between $A$. tuberculatus and A. womersleyi. All the records of $A$. tuberculatus for which we have adequate data are from rainforest litter, so this gap in the distribution of rainforest may be a barrier to its dispersal [11].

This issue looks a bit different in the case of genera. The ranges of the genera interchange along the parallels of altitude, and the equator is the boundary. Some of the genera occur only in one of the two hemispheres. For example, the most typical genera in the northern hemisphere are Trachytes, Cilliba, Urodiaspis, which do not occur in the southern hemisphere. Species from such genera as Rotundabaloghia, Castriidinychus, Platysetosus, Acroseius, and Capricornelia do not occur on the northern hemisphere. The other genera can have different proportions of species occurring on the northern and southern hemisphere (Figure 8). 


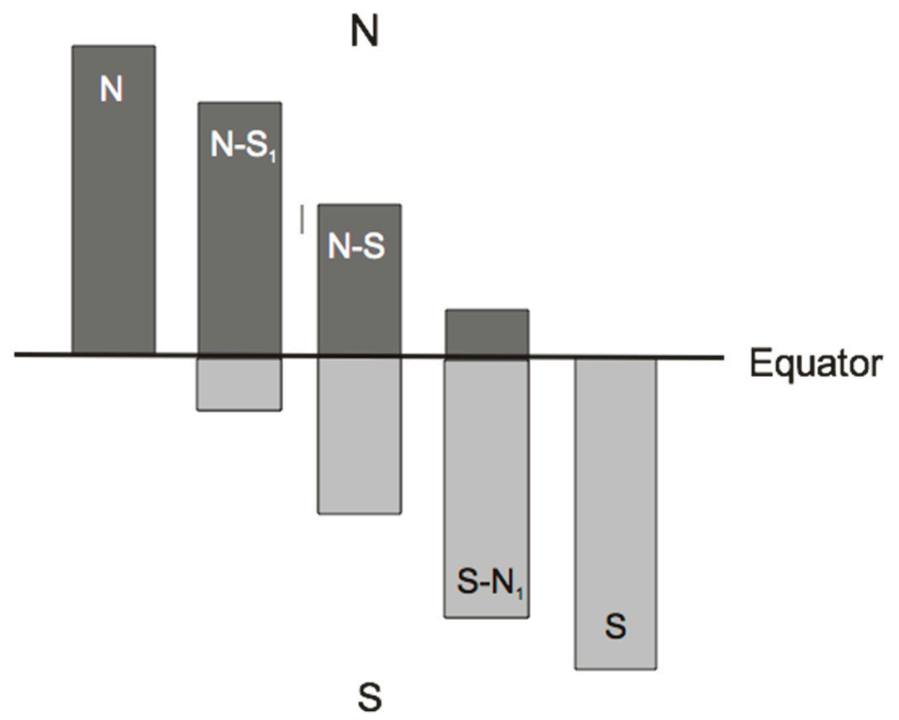

Figure 8. Occurrence of species from particular genera on both hemispheres: $\mathrm{N}$-only in northern hemisphere, $\mathrm{N}-\mathrm{S}_{1}$ - mainly in northern hemisphere, N-S-with the same rate in both hemispheres, $\mathrm{S}-\mathrm{N}_{1}$-with prevailance in southern hemisphere, $\mathrm{S}$ - only in southern hemisphere.

\subsection{Spurious or Real Endemism}

As has been said, geographical ranges of occurrence of most European species of Uropodina have already been described in detail [2-5]. In the case of the other continents, there are in fact no detailed accounts with information about the exact geographical distribution of Uropodina species. Most of the species from other continents were found only in one location and as single specimens. This can be said especially about exotic materials from South America, Australia and Oceania, Africa, and south-eastern Asia. A bit more information is now available about the ranges of Uropodina mites in Australia. More precise studies based on a large number of samples from different locations show the actual ranges of some new species discovered recently [10-12,24]. Thus, the question is whether sporadic occurrences of some species from this group on other continents reflect unique endemism of these mites or whether they stem from the extent to which the geographical distribution of these mites has been already surveyed on every continent, or whether it is a combination of these two factors.

In the first period of research into this group of organisms during the period between 1800 and 1930, the number of described new taxa from all continents was no higher than 100 species in the next decade, whereas between 1970 and 1990 several new species were described every year. The researchers from previous generations, such as Berlese, Oudemans and Sellnick, who only had materials with specimens of Uropodina from places where these mites had not been recorded earlier, did not give any synonyms due to the low number of species described in the literature. The taxa they described at that time (despite the poor quality of these descriptions and very often incorrect systematic status diagnoses) were indeed new species.

The descriptions of new Uropodina species in Europe made during that period (until the Second World War) in many cases have caused a lot of ambiguity. Due to the large number of acarologists interested in this group of mites and the lack of precision in the first descriptions of the oldest species, many species were often described several times under different names, which is evident in the high number of synonyms. Furthermore, contemporary acarologists also often cannot avoid forging new synonyms. This situation stems mainly from the fact that the quality of new descriptions is still often poor and that researchers ignore the evidence preserved in type specimens, but base their descriptions on earlier accounts available in the literature. Unfortunately, it may seem that some acarologists are now focused only on describing new species and they are not interested at all in conducting any research into the biology, ecology, and zoogeography of Uropodina mites. The terse descriptions of new species, which frequently provide no basic information about the biology of the species such as 
variability (geographical and ecological) and range of occurrence, do not allow researchers to classify the species correctly. Besides this, many acarologists interpret all types of variability in the same way, which has an identical impact on speciation, and, as a result, they often end up with another synonym for the species. It should be borne in mind that the verification and re-classification of such data post factum is extremely hard and laborious. In many cases, any verification of the description is very hard or simply impossible due to the lack of access to the type specimen used by the researcher. Finally, new species used to be (and also these days often are) described on the basis of just one specimen, developmental (juvenile) stages, or specimens of only one sex. In this situation, synonyms have already become a commonplace in the literature on Uropodina mites.

Thus, thorough verification of synonyms is in fact one of the major taxonomic problems in this group of mites. The name of a species can indicate whether there is any necessity to check the diagnosis and designation of the species. Hirschmann and his co-workers described a lot of new Uropodina species between 1961 and 1993. Unfortunately, in their descriptions of new species, they did not take into account the geographical and ecological variability of the taxa, regarding all kinds of morphological variability of the specimens as indication of speciation. Moreover, as many of the species that they described turned out to be similar to other species that had been earlier described, they often used "similis" in the name or other terms suggesting similarity to a different species (Table 1).

Most of the 252 species enumerated in Table 1 were recorded only in one location and the number of found specimens was usually very low. It is also noteworthy that almost all the species described as new to science with names suggesting similarity to other taxa, which had been described earlier, usually come from one geographical location (often from the same country). This fact allows us to raise the question whether in both cases it is the same species or not. In such a situation, the overall biodiversity of Uropodina mites would be obviously lower on a given continent or country, but the ranges of occurrence obtained from the verified data on particular taxa would probably give more reliable results, showing their actual geographical distribution. 
Table 1. Morphologically similar species with names suggesting their close genetic relationship listed in the catalogue by Wiśniewski and Hirschmann (1993) ${ }^{1}$.

\begin{tabular}{|c|c|}
\hline Proper Species & Similar Species \\
\hline Baloghibrasiluropoda foveolata Hirschmann, 1973-Brazil & $\begin{array}{l}\text { Baloghibrasiluropoda foveolatasimilis Hirschmann, 1973-Brazil; } \\
\text { Baloghibrasiluropoda foveatoides Hirschmann, 1973-Brazil }\end{array}$ \\
\hline Baloghkaszabia baloghi Hirschmann, 1973—Brazil & Baloghkaszabia baloghisimilis Hirschmann, 1973-Brazil \\
\hline Castriidinychus castri Hirschmann, 1973-Chile & Castriidinychus castrisimilis Hirschmann, 1973-Chile \\
\hline Castriidinychus dentatus (Hirschmann, 1972)—Chile & $\begin{array}{l}\text { Castriidinychus similidentatus Hirschmann, 1973-Chile } \\
\text { Castriidinychus dentatoides Hirschmann, 1973-Chile }\end{array}$ \\
\hline Castriidinychus eupunctatus Hirschmann, 1972-Chile & Castriidinychus eupunctatosimilis Hirschmann, 1972-Chile \\
\hline Clausiadinychus cristatus Sellnick, 1930-Martinique & Clausiadinychus similicristatus Hirschmann, 1973-Brazil \\
\hline Cyllibula (Baloghcyllibula) alta (Sellnick, 1973)—Trinidad & Cyllibula (Baloghcyllibula) altasimilis Hirschmann, 1977)—Bolivia \\
\hline Deraiophorus hirschmanni Hiramatsu, 1977-Japan & Deraiophorus hirschmannisimilis Hiramatsu, 1977-Japan \\
\hline Deraiophorus piriformis Hirschmann, 1973-? & Deraiophorus piriformoides Hirschmann and Hiramatsu, 1990-Philippines \\
\hline Deraiophorus dicornutus Hirschmann, 1973-Bolivia & Deraiophorus dicornutosimilis Hirschmann, 1973-Bolivia \\
\hline Deraiophorus hexacornutus Hirschmann, 1973-New Guinea & Deraiophorus hexacornutosimilis Hirschmann, 1973-New Guinea \\
\hline Deraiophorus penicillatus Hirschmann, 1973-Cejlon & Deraiophorus penicillatasimilis Hirschmann, 1973-Ceylon \\
\hline Deraiophorus loksai Hirschmann, 1973—Brazil, Paragwaj & Deraiophorus loksaisimilis Hirschmann, 1973_Paraguay \\
\hline Deraiophorus kaszabi Hirschmann, 1973—Brazil, Chile & Deraiophorus kaszabisimilis Hirschmann, 1973—Brazil \\
\hline Deraiophorus stammeri Hirschmann and Zirngiebl-Nicol, 1969-Brazil & Deraiophorus stammerisimilis Hirschmann, 1973—Brazil \\
\hline Dinychus carinatus Berlese, 1903-Italy, France, Poland & $\begin{array}{c}\text { Dinychus bincheaecarinatus Hirschmann, Wagrowska-Adamczyk and Zirngiebl-Nicol, } \\
\text { 1984-Germany, France, Slovakia } \\
\text { Dinychus carinatus var. magnus (Athias-Binche, 1980)—France }\end{array}$ \\
\hline Dicourella baloghi Hirschmann and Zirngiebl-Nicol, 1969-Hungary, Romania, Poland & Dicourella baloghisimilis Wiśniewski, 1984-Poland \\
\hline ?? & Discourella crucisimilis Hirschmann, 1972-Paraguay, Brazil \\
\hline Discourella caputmedusae (Berlese and Leonardi, 1901)—Chile & Discourella caputmedusaesimilis Hirschmann, 1972—Chile \\
\hline Discourella modesta (Leonardi, 1899)—Europe & Discourella modestasimilis (Hiramatsu and Hirschmann, 1979)—Canada \\
\hline Discourella rotunda Hirschmann, 1972-Brazil & $\begin{array}{l}\text { Discourella rotunda Hirschmann, 1973-Brazil } \\
\text { Discourella rotundiformis Hirschmann, 1973-Brazil }\end{array}$ \\
\hline
\end{tabular}


Table 1. Cont

\begin{tabular}{|c|c|}
\hline Proper Species & Similar Species \\
\hline Hutufeideria hirschmanni Hiramatsu, 1978-New Guinea & Hutufeideria hirschmannisimilis Hiramatsu, 1980—New Guinea \\
\hline Hutufeideria feideri Hirschmann and Hiramatsu, 1977-New Guinea & Hutufeideria feiderisimilis Hiramatsu, 1981-New Guinea \\
\hline Jerzywisniewska depilata (Trouessart, 1902)_Brazil & Jerzywisniewska depilatasimilis (Wiśniewski, 1902)_Brazil \\
\hline Kaszabjbaloghia kaszabi Hirschmann, 1873-Ecuador & Kaszabjbaloghia kaszabisimilis Hirschmann, 1873-Peru \\
\hline Nenteria oudemansi Hirschmann and Ziringiebl-Nicol, 1969-Netherlands & Nenteria oudemansiformis Hirschmann, 1985-? \\
\hline Nenteria pilosella (Berlese, 1903)_-Italy & Nenteria pilosellapides Hirschmann and Hiramatsu, 1978-Italy \\
\hline Nenteria ritzemai (Oudemans, 1903)—Netherlands, Belgia, Niemcy & Nenteria ritzemaisimilis Hirschmann and Hiramatsu, 1978-Japan \\
\hline Nenteria tropica (Oudemans, 1905)—Togo & Nenteria tropicasimilis Wiśniewski and Hirschamnn, 1985-Guinea \\
\hline Oplitis baloghi Zirngiebl-Nicol and Hirschmann, 1973-Paraguay & Oplitis baloghisimilis Zirngiebl-Nicol and Hirschmann, 1973-Chile \\
\hline Oplitis bispirata (Sellnick, 1954)—Brazil & Oplitis similibispirata Zirngiebl-Nicol, 1973-Bolivia \\
\hline Oplitis castrii Zirngiebl—Nicol and Hirschmann, 1973-Chile & Oplitis castriisimilis Zirngiebl-Nicol and Hirschmann, 1973-Brazil \\
\hline Oplitis mahunkai Zirngiebl—Nicol and Hirschmann, 1973—Brazil & Oplitis mahunkaisimilis Zirngiebl-Nicol and Hirschmann, 1973-Brazil \\
\hline Oplitis minutissima (Berlese, 1903)—Netherlands, Italy, United Kingdom, Ukraine & $\begin{array}{l}\text { Oplitis japanominutissima Hiramatsu, 1979-Japan } \\
\text { Oplitis similiminutissima Hiramatsu, 1979_Japan }\end{array}$ \\
\hline Oplitis dimidiata Hirschmann, 1991—Belize & Oplitis dimidiatasimilis Hirschmann and Wiśniewski, 1991—Cuba \\
\hline Oplitis kaszabii Zirngiebl—Nicol and Hirschmann, 1973—Peru & Oplitis kaszabiisimilis Zirngiebl—Nicol and Hirschmann, 1973—Brazil \\
\hline Oplitis pecki Hirschmann, 1991—Galapagos Islands & Oplitis peckisimilis Hirschmann, 1991—Galapagos Islands \\
\hline Rotundabaloghia baloghi Hirschmann, 1975-New Guinea & $\begin{array}{l}\text { Rotundabaloghia baloghisimilis Hirschmann, 1975-New Guinea } \\
\text { Rotundabaloghia baloghioides Hirschmann, 1975-New Guinea }\end{array}$ \\
\hline Rotundabaloghia incisa Hirschmann, 1992-Peru & Rotundabaloghia incisasimilis Hirschmann, 1992-Peru \\
\hline Rotundabaloghia leteciae Hirschmann, 1992-Colombia & Rotundabaloghia leteciaesimilis Hirschmann, 1992-Colombia \\
\hline Rotundabaloghia soliformis Hirschmann, 1992-Ecuador & Rotundabaloghia soliformoides Hirschmann, 1992-Ecuador \\
\hline Rotundabaloghia haradai Hiramatsu, 1983-Borneo & Rotundabaloghia haradaisimilis Hiramatsu and Hirschmann, 1992-Philippines \\
\hline Rotundabaloghia campanella Hirschmann, 1992-Cameroon & Rotundabaloghia campanellasimilis Hirschmann, 1992-Cameroon \\
\hline Rotundabaloghia kaszabi Hirschmann, 1975-New Guinea & Rotundabaloghia kaszabi Hirschmann, 1975-New Guinea \\
\hline Tetrasejaspis baloghi Hirschmann, 1973-Brazil & Tetrasejaspis baloghisimilis Hirschmann, 1973-Brazil \\
\hline
\end{tabular}


Table 1. Cont

\begin{tabular}{|c|c|}
\hline Proper Species & Similar Species \\
\hline Trachyuropoda arculata Hirschmann, 1975-Brazil & Trachyuropoda similiarculata Hirschmann, 1975-Brazil \\
\hline Trachyuropoda baloghi Hirschmann, 1975-Chile & Trachyuropoda baloghisimilis Hirschmann, 1975-Chile \\
\hline Trachyuropoda coccinea (Michael, 1891)—Europe & Trachyuropoda similicoccinea Hiramatsu, 1979_Japan \\
\hline Trachyuropoda longicornuta Hirschmann, 1976-Spain & Trachyuropoda longicornutasimilis Hirschmann, 1976-?? \\
\hline Trachyuropoda formicaria (Lubbock, 1881)_Europe & Trachyuropoda formicariasimilis Hirschmann, 1975-Russia \\
\hline Trachyuropoda mesofovea Hirschmann, 1976-Paragway & Trachyuropoda mesofoveasimilis Hirschmann, 1976-?? \\
\hline Trachyuropoda schusteri Hirschmann, 1976-Brazil & Trachyuropoda schusterisimilis Hirschmann, 1976-?? \\
\hline Trachyuropoda multituberosa (Willmann, 1951)_Austria & $\begin{array}{l}\text { Trachyuropoda multituberculata Hirschmann, 1976-Spain, Austria } \\
\text { Trachyuropoda tuberosa Hirschmann, 1976-Spain }\end{array}$ \\
\hline Trachyuropoda dicarinata Hirschmann, 1976-Peru & Trachyuropoda dicarinatasimilis Hirschmann, 1976-Peru \\
\hline Trichouropoda polytricha (Vitzthum, 1923)—Central Europe, Turkiestan & Trichouropoda polytrichasimilis Hirschmann, 1972-Portugal \\
\hline Trichouropoda lindquisti Hirschmann, 1978-Canada & Trichouropoda lindquistisimilis Hirschmann, 1978-Canada \\
\hline Trichouropoda afossalis Hirschmann, 1978-Ghana & Trichouropoda afossalisimilis Hirschmann and Wiśniewski, 1987-Indie \\
\hline Trichouropoda denticulata Hirschmann, 1978-USA & Trichouropoda denticulatasimilis Wiśniewski and Hirschmann, 1987-Honduras \\
\hline Trichouropoda ditricha Hirschmann and Wiśniewski, 1987—Ghana & Trichouropoda ditrichasimilis Hirschmann and Wiśniewski, 1987-Cameroon \\
\hline Trichouropoda bipilis (Vitzthum, 1921)—Austria & Trichouropoda similibipilis Hirschmann, 1972-USA \\
\hline Trichouropoda obscura (C. L. Koch, 1836)—Austria & Trichouropoda obscurasimilis Hirschmann and Zirngiebl-Nicol, 1961-Central Europe \\
\hline Trichouropoda punctata Hirschmann and Zirngiebl-Nicol, 1961—Spain, Norway & Trichouropoda punctatasimilis Wiśniewski and Hirschmann, 1986-Poland \\
\hline Trichouropoda javensis (Oudemans, 1901)_Java & $\begin{array}{l}\text { Trichouropoda similijavensis Hiramatsu and Hirschmann, 1979_-Philippines } \\
\text { Trichouropoda philippino javensis Hirschmann and Wiśniewski, 1988-Philippines }\end{array}$ \\
\hline Trichouropoda adifaxa (Vitzthum, 1921)—Spanish Guinea & Trichouropoda adifaxasimilis Hirschmann and Wiśniewski, 1986—Spanish Guinea \\
\hline Trichouropoda endroedyi Hirschmann and Wiśniewski, 1986-Ghana & Trichouropoda endroedyioides Hirschmann and Wiśniewski, 1986-Ghana \\
\hline Trichouropoda ruehmi Hirschmann, 1972-Brazil & Trichouropoda ruehmisimilis Wiśniewski and Hirschmann, 1987_-Brazil \\
\hline Trichouropoda serrata Hirschmann and Zirngiebl-Nicol, 1961-Germany & Trichouropoda serratasimilis Hirschmann and Zirngiebl-Nicol, 1961-Canada \\
\hline Trichouropoda stammeri Hirschmann and Zirngiebl-Nicol, 1969-Hungary & Trichouropoda stammerisimilis Hirschmann, 1978-Poland \\
\hline Trichouropoda sturmii Hirschmann and Wiśniewski, 1987-Colombia & Trichouropoda sturmiisimilis Hirschmann and Wiśniewski, 1987—Colombia \\
\hline
\end{tabular}


Table 1. Cont

\begin{tabular}{|c|c|}
\hline Proper Species & Similar Species \\
\hline $\begin{array}{c}\text { Trichouropoda sturmii Hirschmann and Zirngiebl-Nicol, } 1961 \text { Central and Western } \\
\text { Europe, Mongolia, Siberia }\end{array}$ & Trichouropoda sturmiisimilis Hirschmann and Wiśniewski, 1987-Germany \\
\hline Trichouropoda sellnicki Hirschmann and Zirngiebl-Nicol, 1969_-Bahamas & Trichouropoda sellnickioides Wiśniewski and Hirschmann, 1988-Cuba \\
\hline Trichouropoda solaris Hirschmann, 1972—Brazil & Trichouropoda solarissima Hirschmann, 1978-Bolivia \\
\hline Trichouropoda vanna (Lombardini, 1928)_Brazil & Trichouropoda vannaoides Hirschmann, 1978-Bolivia \\
\hline Trichouropoda quadritricha Hirschmann and Wiśniewski, 1988-Ghana & Trichouropoda quadritrichasimilis Hirschmann and Wiśniewski, 1988-Ghana \\
\hline Trigonuropoda crucistructura Hirschmann, 1975-Sri Lanka & Trigonuropoda crucistructuraoides Hirschmann, 1975—Sri Lanka \\
\hline Trigonuropoda schizostructura Hirschmann, 1975—Sri Lanka & Trigonuropoda schizostructurasimilis Hirschmann, 1975—Sri Lanka \\
\hline Trigonuropoda tuberosa Hirschmann, 1975-New Guinea & Trigonuropoda tuberosasimilis Hirschmann, 1975-New Guinea \\
\hline Trigonuropoda monofoveolata Hirschmann, 1975-New Guinea & Trigonuropoda monofoveolatasimilis Hirschmann, 1975-New Guinea \\
\hline Trigonuropoda sanguinea Hirschmann and Hiramatsu, 1977-Japan & Trigonuropoda sanguineasimilis Hirschmann and Hiramatsu, 1977-Taiwan \\
\hline Trigonuropoda tuberculata Hirschmann, 1975-New Guinea & Trigonuropoda tuberculatasimilis Hiramatsu, 1979_Japan \\
\hline Trigonuropoda terra-reginae Domrow, 1957-Australia & Trigonuropoda terra-reginaesimilis Hirschmann, 1975-Australia \\
\hline Trigonuropoda trioculata Hirschmann, 1975-Australia & Trigonuropoda trioculatasimilis Hirschmann, 1975-Australia \\
\hline Trigonuropoda trichobaloghia Hirschmann, 1975-Peru & Trigonuropoda trichobaloghiasimilis Hirschmann, 1975-New Guinea \\
\hline Trigonuropoda pontina Hirschmann, 1975-Ceylon & Trigonuropoda trichopontina Hirschmann, 1975—Sri Lanka \\
\hline Uroactinia hippocrepea (Berlese, 1918)-Thaiti & Uroactinia hippocrepoides (Vitzthum, 1935)—Marquesas Islands \\
\hline Urodiaspis religiosa Hiramatsu, 1979_Japan & Urodiaspis similireligiosa Hiramatsu, 1979_Japan \\
\hline Uroobovella costai Hirschmann and Zirngiebl-Nicol, 1972-Israel, Romania, Greenland & Uroobovella costaisimilis Wiśniewski, 1980—New Guinea \\
\hline Uroobovella faceta Hiramatsu and Hirschmann, 1978-Ecuador & Uroobovella facetaoides Hiramatsu and Hirschmann, 1978-New Guinea \\
\hline Uroobovella pectinata (Hirschmann, 1973)—New Guinea & Uroobovella pectinatasimilis Hiramatsu, 1980-Indonezja \\
\hline Uroobovella fimicola (Berlese, 1903)_Europe & Uroobovella fimicolasimilis Hirschmann and Zirngiebl-Nicol, 1972-Chile \\
\hline Uroobovella flagelliger (Berlese, 1910)_Italy, Sweden, Germany, Switzerland, Europe & Uroobovella flagelligerformis Hirschmann, 1979—Canada \\
\hline Uroobovella foveolata Hirschmann and Zirngiebl-Nicol, 1972-France & Uroobovella foveolatasimilis Hiramatsu, 1980-Japan \\
\hline Uroobovella ipidis (Vitzthum, 1923)—Europe, Lebanon & Uroobovella ipidisimilis Hirschmann and Zirngiebl-Nicol, 1962-Germany, Poland \\
\hline
\end{tabular}


Table 1. Cont

\begin{tabular}{|c|c|}
\hline Proper Species & Similar Species \\
\hline Uroobovella orri Hirschmann, 1972-USA & Uroobovella orrisimilis Hirschmann and Zirngiebl-Nicol, 1975-Australia \\
\hline Uroobovella obovata (Canestrini and Berlese, 1884)_Europe & Uroobovella similiobovata Hirschmann and Zirngiebl-Nicol, 1962-Germany, Rumunia \\
\hline Uroobovella ovalis Hirschmann and Zirngiebl-Nicol, 1962-Germany & Uroobovella similiovalis Hirschmann and Zirngiebl-Nicol, 1979-Germany \\
\hline Uroobovella pauxila Hiramatsu, 1981—New Guinea & Uroobovella pauxiloides Hirschmann, 1981-Vietnam \\
\hline Uroobovella takakii Hiramatsu, 1980-Japan & Uroobovella similitakakensis Hirschmann, 1981-Vietnam \\
\hline Uroobovella portalis Hirschmann, 1973-Brazil & Uroobovella portalisimilis Hirschmann, 1981—Brazil \\
\hline Uroobovella nova (Oudemans, 1902-Europe & Uroobovella novasimilis Hiramatsu, 1979_Japan \\
\hline Uroobovella Zaireensis Hirschmann, 1981-Zaire & Uroobovella similiZaireensis Hirschmann, 1981-USA \\
\hline Uroobovella vitzthumi Hirschmann and Zirngiebl-Nicol, 1962-?? & Uroobovella vitzthumisimilis Hirschmann, 1973-Paraguay \\
\hline Uropoda (Metadinychus) serrata Hirschmann, 1972-Paraguay & Uropoda (Metadinychus) serratasimilis Hiramatsu and Hirschmann, 1972-Bolivia \\
\hline Uropoda (Metadinychus) argasiformis (Berlese, 1916)—Brazil, Bolivia & Uropoda (Metadinychus) similiargasiformis Hirschmann, 1981-Zaire \\
\hline Cilliba cassidea (Hermann, 1804)_Europe & Cilliba cassideasimilis Błoszyk, Stachowiak and Halliday, 2006-Central Europe \\
\hline Uropoda (Phaulodinychus) amani Hirschmann, 1973-East Africa & Uropoda (Phaulodinychus) amanisimilis Wiśniewski, 1980-Bismarck Archipelago \\
\hline Uropoda (Phaulodinychus) difoveolata Hirschmann and Zirngiebl-Nicol, 1969-Brazil & Uropoda (Phaulodinychus) difoveolatasimilis Hirschmann, 1972-Brazil \\
\hline Uropoda (Phaulodinychus) quadridentata Hirschmann, 1973-Ecuador & Uropoda (Phaulodinychus) quadridentatasimilis Hiramatsu, 1980-Brazil \\
\hline Uropoda (Phaulodinychus) hiramatsui Hirschmann, 1976-New Guinea & $\begin{array}{l}\text { Uropoda (Phaulodinychus) hiramatsuiformis Hirschmann, 1976-New Guinea } \\
\text { Uropoda (Phaulodinychus) hiramatsuioides Hirschmann, 1976-New Guinea } \\
\text { Uropoda (Phaulodinychus) hiramatsuisimilis Hirschmann, 1976-New Guinea }\end{array}$ \\
\hline Uropoda (Phaulodinychus) hamulifera Michael, 1894-Europe & Uropoda (Phaulodinychus) similihamulifera Hiramatsu, 1894-Japan \\
\hline Uropoda (Phaulodinychus) stolida Hiramatsu and Hirschmann, 1978-Peru & Uropoda (Phaulodinychus) stolidasimilis Hiramatsu and Hirschmann, 1979_Peru \\
\hline Uropoda (Uropoda) orbicularis (Muller, 1776)—Europe & $\begin{array}{l}\text { Uropoda (Uropoda) japanoorbicularis Hiramatsu, 1979-Japan } \\
\text { Uropoda (Uropoda) onishiiorbicularis Hiramatsu, 1980-Japan } \\
\text { Uropoda (Uropoda) similiorbicularis Hiramatsu, 1980-Japan }\end{array}$ \\
\hline Uropoda (Phaulodinychus) penicillata Hirschmann and Zirngiebl-Nicol, 1969_Panama & Uropoda (Phaulodinychus) penicillatasimilis Hirschmann, 1972-Brazil \\
\hline Uropoda (Phaulodinychus) procera Hiramatsu and Hirschmann, 1979-Meksyk & Uropoda (Phaulodinychus) procerasimilis Hiramatsu and Hirschmann, 1979-Mexico \\
\hline Uropoda (Phaulodinychus) regia (Vitzthum, 1921)—Bolivia & Uropoda (Phaulodinychus) regiasimilis Hirschmann, 1972-Brazil \\
\hline Uropoda (Phaulodinychus) Braziliensis (Sellnick, 1962)—Brazil & Uropoda (Phaulodinychus) similiBraziliensis Hirschmann, 1972- Paragway \\
\hline Uropoda (Phaulodinychus) insulana Hiramatsu, 1979_Japan & Uropoda (Phaulodinychus) insulanasimilis Hiramatsu, 1981-Japan \\
\hline
\end{tabular}


Table 1. Cont

\begin{tabular}{|c|c|}
\hline Proper Species & Similar Species \\
\hline Uropoda (Phaulodinychus) porticensis (Berlese, 1903)—Italy & Uropoda (Phaulodinychus) porticensoides Hirschmann, 1993-Switzerland \\
\hline Uropoda (Phaulodinychus) morikawai Hiramatsu, 1978-Japan & Uropoda (Phaulodinychus) similimorikawai Hiramatsu, 1979-Japan \\
\hline Uropoda (Phaulodinychus) tropicana Hiramatsu, 1978-New Guinea & Uropoda (Phaulodinychus) tropicanasimilis Hiramatsu, 1981-New Guinea \\
\hline Uropoda (Phaulodinychus) ungulata Hirschmann and Hiramatsu, 1977-Ecuador & Uropoda (Phaulodinychus) ungulatasimilis Hirschmann and Hiramatsu, 1979_Ecuador \\
\hline
\end{tabular}

${ }^{1}$ The names given here are from the catalogue. 


\subsubsection{Example I: Mites from the Genus Rotundabalogia from South America}

To analyze the extent of endemism among Uropodina mites on the basis of the evidence in the literature on the topic, we analyzed mites from the genus Rotundabalogia. In 1992, Hirschmann [25] described 65 species from this genus from a few countries in South America. The specimens were extracted from samples collected at 18 sites located in Colombia, Ecuador, Venezuela, Brazil, Peru, and Bolivia (Figure 9).

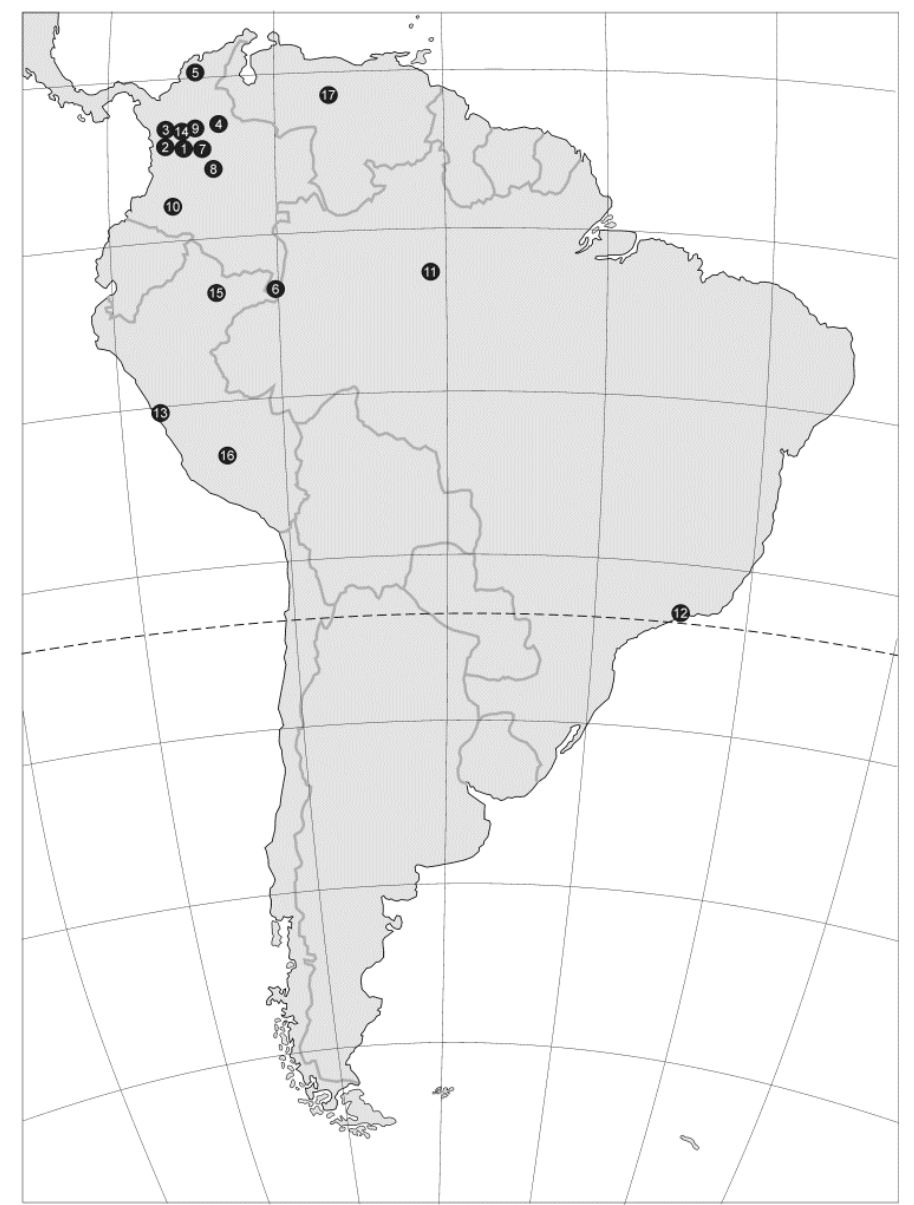

Figure 9. Locations of the species from the genus Rotundabaloghia described by Hirschmann in 1992 [25] from the area of South America.

The most striking thing here is the number of found species in the locations marked on the map-the number fluctuated between one and nine (Table 2). For example, in Europe it is very hard to find in one sample more than two species of the same genus (Błoszyk-unpublished data). Finding between seven and nine species from the genus Rotundabaloghia in a few sites $(1,13,14,15)$ can indicate a very fast pace of speciation in a given area or incorrect classification at the level of genus. However, the lack of any descriptions of the microhabitats in which the samples were collected does not allow us to verify the latter presumption. On the other hand, it is also possible that rainforests offer extremely favorable environmental conditions, enhancing the fast speciation of these mites, which can easily adapt to different types of microhabitats by modification of their body size and morphology. 
Table 2. List of species from the genus Rotundabaloghia described by Hirschmann in 1992 [25] from the area of South America (numbers of sites are the same as on the map). Species in bold were found in more than one location.

\begin{tabular}{|c|c|c|c|}
\hline No & Country & Location & Species \\
\hline 1 & Colombia & Monserrate & $\begin{array}{c}\text { Rotundabalogia lamellosa Hirschmann, 1992; } \\
\text { Rotundabaloghia tetraclavata Hirschmann, 1992; } \\
\text { Rotundabaloghia chisacaensis Hirschmann, 1992; } \\
\text { Rotundabaloghia monserratensisHirschmann, 1992; } \\
\text { Rotundabaloghia monterredondoensis Hirschmann, 1992; } \\
\text { Rotundabaloghia silvacola Hirschmann, 1992; } \\
\text { Rotundabaloghia humicola Hirschmann, 1992; } \\
\text { Rotundabaloghia bosquensis Hirschmann, 1992; } \\
\text { Rotundabaloghia fincae Hirschmann, 1992; }\end{array}$ \\
\hline
\end{tabular}

2 Colombia Alto Belem
Rotundabaloghia forcipata Hirschmann, 1992;

Rotundabaloghia hexaspinosa Hirschmann, 1992;

Rotundabaloghia belemensis Hirschmann, 1992; Rotundabaloghia altoensis Hirschmann, 1992;

Rotundabaloghia pituitosa Hirschmann, 1992;

Rotundabaloghia sexspinosa Hirschmann, 1992; Rotundabaloghia diclavata Hirschmann, 1992; Rotundabaloghia flava Hirschmann, 1992;

Rotundabaloghia guerreroensis Hirschmann, 1992;

\begin{tabular}{|c|c|c|c|}
\hline 4 & Colombia & Paramo & Rotundabaloghia hexaspinosa Hirschmann, 1992; \\
\hline 5 & Colombia & La Rusia & Rotundabaloghia hexaspinosa Hirschmann, 1992; \\
\hline 6 & Colombia & Letecia & $\begin{array}{l}\text { Rotundabaloghia hexaspinosa Hirschmann, 1992; } \\
\text { Rotundabaloghia amazonasae Hirschmann, 1992; } \\
\text { Rotundabaloghia leteciae Hirschmann, 1992; } \\
\text { Rotundabaloghia leteciasimilis Hirschmann, 1992; }\end{array}$ \\
\hline
\end{tabular}

Rotundabaloghia sexspinosa Hirschmann, 1992;

Rotundabaloghia octospinosa Hirschmann, 1992;

$7 \quad$ Colombia Chingaza

Rotundabaloghia tetraclavata Hirschmann, 1992;

Rotundabaloghia chingazensis Hirschmann, 1992;

\begin{tabular}{|c|c|c|c|}
\hline 8 & Colombia & $\begin{array}{l}\text { La Calera; } \\
\text { Bogota; } \\
\text { Chisaca }\end{array}$ & $\begin{array}{l}\text { Rotundabaloghia tetraclavata Hirschmann, 1992; } \\
\text { Rotundabaloghia diclavata Hirschmann, 1992; } \\
\text { Rotundabaloghia chisacaensis Hirschmann, 1992; } \\
\text { Rotundabaloghia pajonalis Hirschmann, 1992; }\end{array}$ \\
\hline 9 & Colombia & La Tagua & Rotundabaloghia tague Hirschmann, 1992; \\
\hline 10 & Colombia & Huila Resina & $\begin{array}{l}\text { Rotundabaloghia hullae Hirschmann, 1992; } \\
\text { Rotundabaloghia resinae Hirschmann, 1992; }\end{array}$ \\
\hline 11 & Brazil & Manaus & $\begin{array}{l}\text { Rotundabaloghia tetraunguiseta Hirschmann, 1992; } \\
\text { Rotundabaloghia manausensis Hirschmann, 1992; }\end{array}$ \\
\hline 12 & Brazil & Santos & Rotundabaloghia hexaunguiseta Hirschmann, 1992; \\
\hline 13 & Peru & Lima-Pucallpa & $\begin{array}{l}\text { Rotundabaloghia limae Hirschmann, 1992; } \\
\text { Rotundabaloghia duodecimsetae Hirschmann, 1992; } \\
\text { Rotundabaloghia limae Hirschmann, 1992; } \\
\text { Rotundabaloghia magnioperculi Hirschmann, 1992; } \\
\text { Rotundabaloghia ucayali Hirschmann, 1992; } \\
\text { Rotundabaloghia vonalis Hirschmann, 1992; } \\
\text { Rotundabaloghia peruensis Hirschmann, 1992; }\end{array}$ \\
\hline 14 & Ecuador & Quito-Bacza & $\begin{array}{l}\text { Rotundabaloghia ovaligynella Hirschmann, 1992; } \\
\text { Rotundabaloghia soliformoides Hirschmann, 1992; } \\
\text { Rotundabaloghia quitoaensis Hirschmann, 1992; } \\
\text { Rotundabaloghia magna Hirschmann, 1992; } \\
\text { Rotundabaloghia soliformis Hirschmann, 1992; } \\
\text { Rotundabaloghia linguaeformis Hirschmann, 1992; } \\
\text { Rotundabaloghia baczaensis Hirschmann, 1992; } \\
\text { Rotundabaloghia maculosa Hirschmann, 1992; } \\
\text { Rotundabaloghia equadorensis Hirschmann, 1992; }\end{array}$ \\
\hline
\end{tabular}


Table 2. Cont.

\begin{tabular}{cccc}
\hline No & Country & Location & Species \\
\hline & & Rotundabaloghia incisasimilis Hirschmann, 1992; \\
Rotundabaloghia incisa Hirschmann, 1992; \\
Rotundabaloghia iquitosensis Hirschmann, 1992; \\
Rotundabaloghia iquitosensoides Hirschmann, 1992; \\
Rotundabaloghia pucallpae Hirschmann, 1992; \\
Rotundabaloghia maranonensis Hirschmann, 1992; \\
\end{tabular}

Out of 65 species described as being new to science, Hirschmann (1992) found only three of them in more than one location (Table 2). The most striking thing is that the species which were found in several different sites occurred in Colombia, which is the country that Hirschmann examined most thoroughly. This means that the extent of endemism in this group decreases proportionally to the extent to which a given country has been examined.

3.2.2. Example II: Uropoda (Phaulodinychus) penicillata Hirschmann et Zirgiebl-Nicol, 1969 from Ecuador

In order to prove empirically our hypothesis, we also used extensive material collected in the area of Ecuador focusing on one species-Uropoda (Phaulodinychus) penicillata Hirschmann and Zirgiebl-Nicol, 1969 (Figure 10).
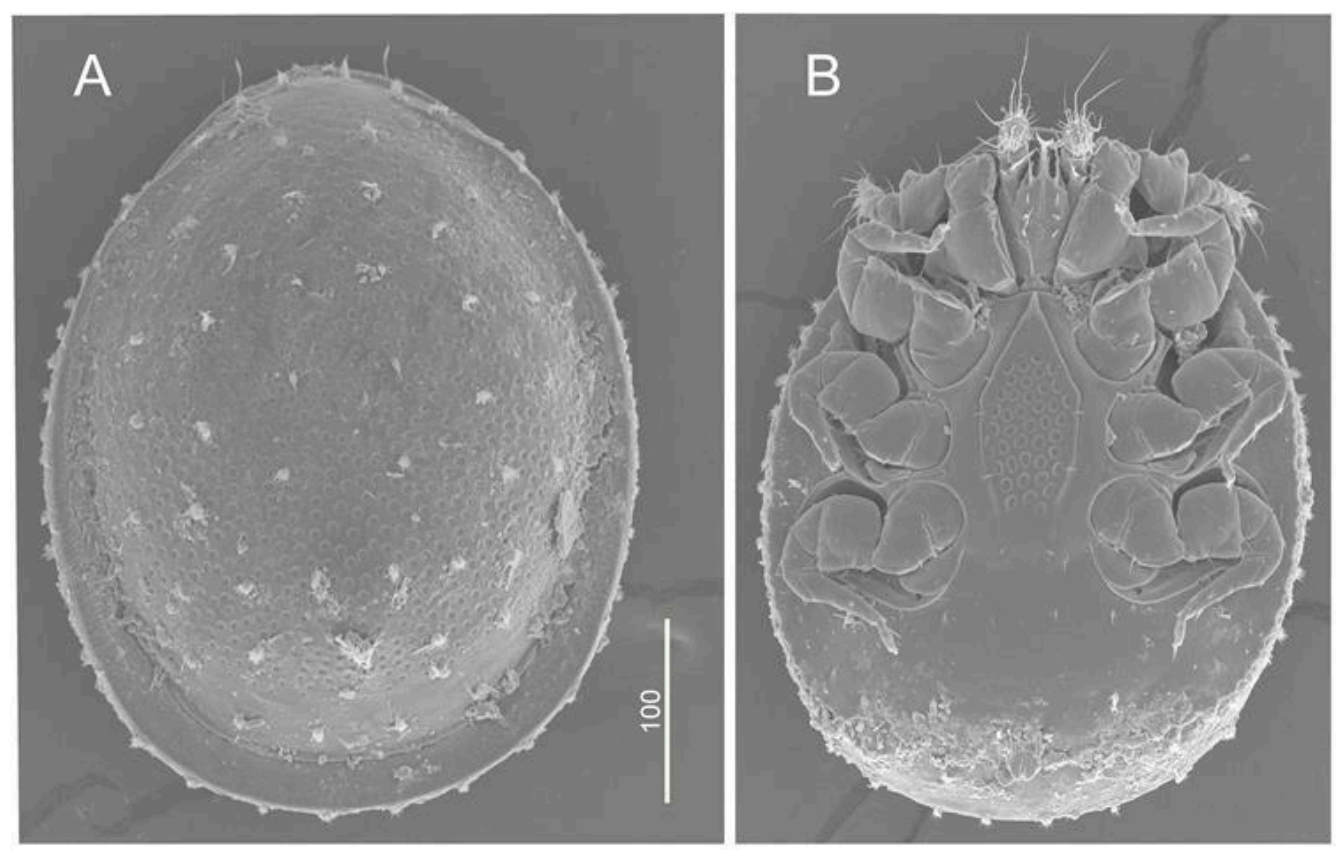

Figure 10. Penicillaturopoda pennicillata, female from Ecuador: (A) dorsal side, (B) ventral side.

The name of this species was used for the first time in the literature in 1964 [26], but with no detailed description and information about the place of occurrence (only a drawing of the genital shield and the ratio of its length to width were given by the author), and thus, it should be regarded as a nomenum nudum. The second time this name was used in Acarologie Folge 8, Teil 9 one year later 
(1965) [27]. This time, a figure showing the hypostome and the dorsal side was given, but still with no information about the exact location in which the species was found. A more detailed description of the species with a location (Panama) was given in Acarologie Folge 12 (1969) (Hirschmann, Zirngiebl-Nicol 1969) [28], with figures showing the ventral side, chelicerae, and epistome. However, the description contained an error in the reference to the figure presented in Folge 7. Hirschmann $(1972 a, b)[29,30]$ established the Uropoda (Phaulodinychus) penicillata species group. In 1972, Hirschamnn described a morphologically identical species from Brazil (Figure 11). Due to the fact that the locations of the two species are $5000 \mathrm{~km}$ away from each other, he thought that they were two separate species. However, he noticed the striking similarity of the described taxon to $U$. (P.) penicillata, classifying it as a new species and he gave it a new name Uropoda (Phaulodinychus) penicillatasimilis. Then he changed the taxonomic status of the $U$. (P.) penicillata species group to the genus level, as Penicillaturopoda [31]. Finally, the penicillata species group [2] included six species (including Berlese species complicate).

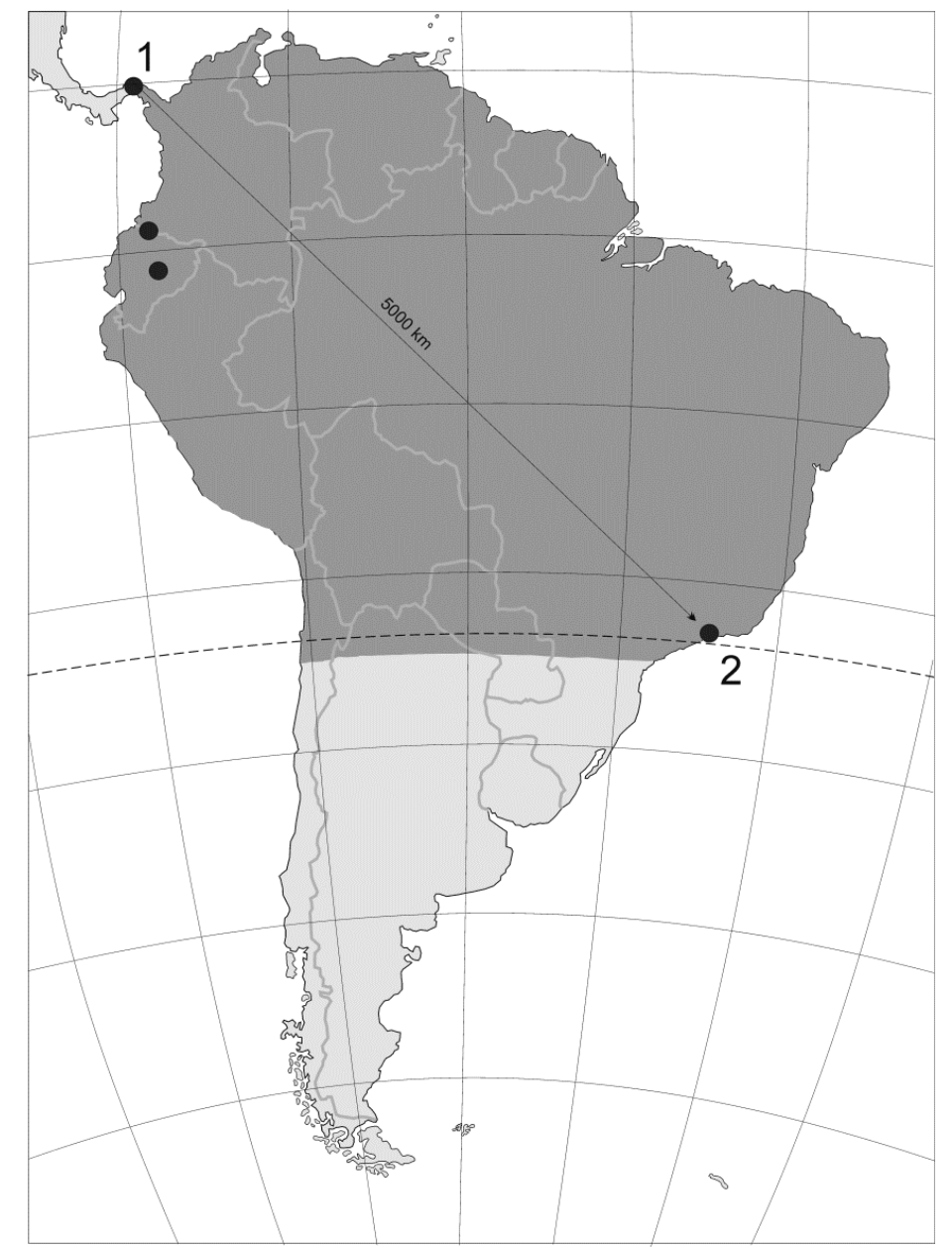

Figure 11. Distribution of recorded sites with Penicillaturopoda pennicillata; 1 -specimens described by Hirschmann and Zirgiebl-Nicol in 1969 as Uropoda (Phaulodinychus) penicillata; 2-specimens described by Hirschamnn in 1972 as Uropoda (Phaulodinychus) penicillatasimilis; •- - unmarked sites on which soil samples were collected in Ecuador in 2014. Gray colour is used to mark areas with potential occurrence of species.

In 2014, the Natural History Collections (Faculty of Biology at AMU, Poznań, Poland) acquired a large collection of over 70 soil samples from Ecuador. The material, which was collected in different locations, contained numerous specimens of $U$. (P.) penicillata (see Appendix A).

Having analyzed the variability of the morphological characteristics used by Hirschmann (1972a,b) [29,30] and Hirschmanna and Hiramatsu (1990) [32] as the basis for discerning new species, 
we claim that both $U$. (P.) pennicillata from Panama and $U$. (P.) pennicillatasimilis from Brazil, as well as the specimens from Ecuador that we analyzed, should be in fact classified as one species. In our opinion, the observed differences (e.g., body size of the specimens, chaetotaxy, and surface sculpture) meet the criteria of population variability, and they stem from the very broad range of occurrence of this species. In Ecuador, this species occurred in 18 out of 78 analyzed samples (frequency $24 \%$ ). The species was recorded mainly in synantropic habitats, with interference of humans, such as greenbelts near busy roads, city parks and agriculture fields. Thus, the species is presumably very common in the tropical zone in two subregions of the Neotropical region (Mexican and Brazilian) (Figure 11).

The examples given above are only a few of many other instances of the so-called "spurious endemism" which can be observed among Uropodina species. This phenomenon can be explained by the fact that the distribution of most species from this group presented in the literature on some continents has been recorded so far only in a few places. As the examples given above show, this situation stems mainly from the current state of knowledge in this field of research and erroneous designation of some species, and not from the actual range of occurrence of the described species.

The results of research into the geographical distribution of particular species of Uropodina mites in Europe, especially in Poland, show, however, that these mites in many cases apparently have a narrow range of occurrence (Figures 2-6). This means that they are more prone to endemism than, for example, Oribatida [33-35]. Other groups of mites which are similar in this respect to Uropodina are in Poland species from the family Labidostommidae (Prostigmata) and Zerconidae (Mesostigmata) [36,37]. Species from both these groups have their range boundaries in Poland, which often overlap with those of Uropodina mites. However, it is noteworthy that the area of Europe has been more thoroughly analyzed in this respect than other continents, and therefore, the ranges given in the literature reflect the actual geographical distribution of the species than only occasional occurrences of a large number of species, which can be observed in tropical regions.

One should also bare in mind that rain forests on all continents due to their unique ecological diversity of niches are extremely favorable ecosystems for fast speciation of many groups of organisms, including Uropodina mites, and therefore, they are also places with the highest biodiversity. Our knowledge about acarofauna of such ecosystems is still far from complete. On the other hand, the gradual shrinking of rain forest observed during the last couple of decades on a global scale should encourage experts to further carry out more extensive research. If it is true that these mites indeed have such a strong natural tendency towards endemism, then every loss of a bit of area of a rain forest in different geographical regions means loss of many species of Uropodina mites.

\section{Conclusions}

One of the aims of the current study was to show that such problems occur not only in the taxonomy of Uropodina. Our intention was to make other researchers pay more attention to the need for more thorough acarological research that would not be confined only to describing new species, but it would also allow us to ascertain the actual geographical distribution of already classified species, and would provide more information about the biology and ecology of the species. Due to the high level of biodiversity among Uropodina mites, any further research should be more extensive and it should be conducted on all continents. Recording as many new species as possible will also allow us to verify the systematic classification of this group at the level of higher taxonomic classes (i.e., genera and families). Moreover, there is also an urgent need for providing new descriptions of most species that would be based on a large series of specimens, especially those described until the end of the first half of the last century, and they would rest on both morphological data obtained with SEM techniques and on the molecular biology techniques, as DNA barcoding, to identify species. To do that, researchers should organize special expeditions to places which are particularly endangered, the so-called hot-spots, and then the collected material should be deposited in natural history museums, which later could make them available to other acarologists. In Poland, there is such a natural history 
museum department at the Faculty of Biology at Adam Mickiewicz University in Poznań, and it is called the Natural History Collections.

Author Contributions: Conceptualization, J.B. and A.N.; Methodology, J.B.; Software, J.B.; Validation, J.B., A.N.; Formal Analysis, J.B. and A.N.; Investigation, J.B. and A.N.; Resources, J.B. and A.N.; Data Curation, J.B.; Writing-Original Draft Preparation, J.B. and A.N.; Writing-Review \& Editing, A.N.; Visualization, J.B. and A.N.; Supervision, A.N.; Project Administration, J.B.; Funding Acquisition, J.B. and A.N. All authors have read and agreed to the published version of the manuscript.

Funding: This work was partially funded by the Prometeo Project of the Secretariat for Higher Education, Science, Technology and Innovation of the Republic of Ecuador (grant to Łukasz Kaczmarek, permit No 001-15IC-FLO-FAU-DNB/MA from Ministry of Environment in Ecuador) and by Polish Ministry of Science and Higher Education, project number N303 091 32/3082. This work was also partially funded from financial resources of the Faculty of Biology at Adam Mickiewicz University in Poznań.

Acknowledgments: The authors would like to thank CSIRO (Canberra, Australia) for providing facilities for laboratory and field research, and the National Parks authorities of Victoria and New South Wales for permission to collect samples in their respective states. We also thank Łukasz Kaczmarek for collecting and sharing samples in Ecuador, thank Zbigniew Adamski from Electron and Confocal Microscope Laboratory, Faculty of Biology, Adam Mickiewicz University in Poznan, for taking the SEM images.

Conflicts of Interest: The authors declare no conflict of interest.

\section{Appendix A}

Sites with Penicillaturopoda pennicillata mentioned in the literature and found in our own materials:

Panama, dead wood collected near Colon, $9^{\circ} 20^{\prime \prime}$ N 79 53" W. Brazil, Santos, Sao Paulo State, 29. IX 1967, transect on steep hills of a plateau near a coast, at approx. 400-500 m, secondary forest on a steep hill, $23^{\circ} 57^{\prime \prime} \mathrm{S} 46^{\circ} 21^{\prime \prime} \mathrm{W}$, leg. J. Balogh: from touchwood near a watercourse [BRB44]; damp moss on stones [BRB45]; dense moss with touchwood [BRB46]; Material examined. Ecuador. 16 Female, CIPCA (Centro de Investigación Posgrado y Conservación Amazónica ang. Centre of Research, Graduate and Amazon Conservation), 28 XI 2014, $01.48200^{\circ} \mathrm{S} 78.00205^{\circ} \mathrm{W}$, corn and papa china field, quantitative sample, leg. Ł. Kaczmarek [EKW-041]; 1 DN, 1 LV, Urban, Puyo, 19 X 2014, $01.48834^{\circ} \mathrm{S} 78.00355^{\circ} \mathrm{W}$, near a watercourse/stream, leg. Ł. Kaczmarek [EKW-001]; 1 female, 1DN, $1 \mathrm{LV}$, Agriculture, CIPCA, 14 XI 2014, $01.23710^{\circ} \mathrm{S} 77.88805^{\circ} \mathrm{W}$, between banana and cocoa trees, leg. $\mathrm{七}$. Kaczmarek, [EKW-002]; 2 females, 1 DN, Urban, Puyo, 14 X 2014, 01.49291 S 78.00056 ${ }^{\circ}$ W, greenbelt between road lanes near Megaldaz, leg. Ł. Kaczmarek, [EKW-006]; 1DN, Urban, Puyo, 4 XI 2014, $01.47986^{\circ} \mathrm{S} 78.00068^{\circ} \mathrm{W}$, near a sawmill, leg. Ł. Kaczmarek, EKW-007; 1 famale, Agriculture, CIPCA, 14 XI 2014, $01.23710^{\circ} \mathrm{S} 77.88805^{\circ} \mathrm{W}$, between banana and cocoa trees, leg. Ł. Kaczmarek, EKW-011; 1 female, 3 DN, Urban Puyo, $14 X 2014,01.48535^{\circ} \mathrm{S} 77.99717^{\circ} \mathrm{W}$, in a park at a palm tree, leg. . Kaczmarek, [EKW-013]; 1 female, 1 DN, Agriculture, CIPCA, 24 XI 2014, 01.23710 $\mathrm{S} 77.88805^{\circ} \mathrm{W}$, among banana trees, leg. Ł. Kaczmarek, [EKW-015]; 3 females, Urban, Puyo, 14 X 2014, $01.49017^{\circ} \mathrm{S}$ 77.99918 W, city center, near a watercourse, at a tree, leg. Ł. Kaczmarek, [EKW-016]; 1 DN, 1 LV, Urban, Puyo, 19 X 2014, $01.48062^{\circ} \mathrm{S} 78.00282^{\circ} \mathrm{W}$, a park along a river, leg. Ł. Kaczmarek, [EKW-019]; 7 females, 1 DN, 1 PN, Urban, Puyo, 4 XI 2014, $01.48200^{\circ}$ S 78.00205 W, city of Puyo, a small green area between two streets Manabí and Galapagos, near a tree, leg. Ł. Kaczmarek, [EKW-024]; 2 females, Urban, Puyo, 27 X 2015, $01.48018^{\circ}$ S 78.00538 W , at a tree. Leg. Ł. Kaczmarek, [EKW-026]; 2 females, 1 DN, piedmont tropical forest, $8 \mathrm{I} 2015,00.83029^{\circ} \mathrm{N} 78.40355^{\circ} \mathrm{W}$, near road E10, approx. $10 \mathrm{~km} \mathrm{SE}$ from Lita, litter from deciduous forest, leg. Ł. Kaczmarek, [EKW-029]; 1 female, Agriculture, CIPCA, 24 XI $2014,01.23710^{\circ} \mathrm{S} 77.88805^{\circ} \mathrm{W}$, among banana trees, [EKW-042]; 9 females, $2 \mathrm{DN}$, Agriculture, CIPCA, 28 XI 2014, $01.23710^{\circ} \mathrm{S} 77.88805^{\circ} \mathrm{W}$, on a corn and papachina field, leg. Ł. Kaczmarek, [EKW-045]; 11 females, $1 \mathrm{DN}$, Agriculture, CIPCA, 28 XI 2014, $01.23710^{\circ} \mathrm{S} 77.88805^{\circ} \mathrm{W}$, on a corn and papachina field, leg. Ł. Kaczmarek, [EKW-048]; 1 female, Agriculture, CIPCA, 20 XI 2014, 01.23710 ${ }^{\circ}$ 77.88805 ${ }^{\circ}$ W, among cocoa trees, leg. Ł. Kaczmarek, [EKW-050]; 1 PN, Agriculture, CIPCA, 20 XI 2014, 01.23710 S $77.88805^{\circ} \mathrm{W}$, among cocoa trees, leg. Ł. Kaczmarek, [EKW-051]. 


\section{References}

1. Müller, O.F. Zoologiae Danicae Prodromus, seu Animalism Daniae et Norvegien Indigenarum. Characteres, Nomina et Synonyma Imprimis Populariarum; Havniae, Typis Hallageriis: Copenhagen, Denmark, 1776; pp. 186-187.

2. Wiśniewski, J.; Hirschmann, W. Katalog der Ganggattungen, Untergattungen, Gruppen und Arten der Uropodiden der Erde (Taxonomie, Literatur, Grősse, Verbreitung, Vorkommen). Gangsystematic der Parasitiformes 548. Acarologie 1993, 40, 1-220.

3. Błoszyk, J. Geograficzne i Ekologiczne Zróżnicowanie Zgrupowań Roztoczy z Kohorty Uropodina (Acari: Mesostigmata) w Polsce. 1. Uropodina Lasów Gradowych (Carpinion betuli); Kontekst: Poznań, Poland, 1999; p. 245.

4. Mašán, P. Mites of the cohort Uropodina (Acarina, Mesostigmata) in Slovakia. Annot. Zool. Bot. Bratislava. 2001, 223, 1-320.

5. Błoszyk, J.; Bajaczyk, R.; Markowicz, M.; Gulvik, M. Geographical and ecological variability of mites of the suborder Uropodina (Acari: Mesostigmata) in Europe. Biol. Lett. 2003, 40, 15-35.

6. Błoszyk, J. East Carpathian geographical elements in the mite fauna of Poland. Biol. Lett. 1998, 35, $137-147$.

7. Błoszyk, J.; Bajaczyk, R.; Błoszyk, G.; Napierała, A. Uropodina (Acari: Mesostigmata) parków narodowych Polski na tle innych obszarów. Kosmos 2002, 51, 463-470.

8. Napierała, A.; Błoszyk, J.; Kozak, J.; Bruin, J. Spatial distribution of mites of the suborder Uropodina (Acari: Mesostigmata) in small isolated forest area. Exp. Appl. Acarol. 2006, 39, 289-295. [CrossRef]

9. Athias-Binche, F.; Błoszyk, J. Australian Uropodina (Acari: Anactonotrichida). 1. Australocilliba gen.n. (Cillibidae). J. Aust. Ent. Soc. 1988, 27, 1-8. [CrossRef]

10. Błoszyk, J.; Halliday, R.B.; Dylewska, M. Acroseius womersleyi gen. nov., sp. nov., a new genus and species of Uropodina from Australia (Acari: Trachytidae). Syst. Appl. Acarol. 2005, 10, 41-60. [CrossRef]

11. Błoszyk, J.; Halliday, R.B.; Napierała, A. Acroseius weiri sp. nov. (Acari: Trachytidae), a new species of Uropodina from eastern Australia, with notes on the biogeography of the genus. Syst. Appl. Acarol. 2013, 18, 273-290.

12. Błoszyk, J.; Halliday, R.B.; Adamski, Z.; Książkiewicz-Parulska, Z. Capricornella bicornuta, a new genus and species of mite from eastern Australia (Acari: Uropodina). Zootaxa 2017, 4244, 321-338. [CrossRef]

13. Błoszyk, J.; Szymkowiak, P. Trachytes kaliszewskii n. sp. (Acari: Uropodina) from Great Basin (Utah, USA), with remarks on the habitats and distribution of the members of the genus Trachytes. Great Basin Nat. 1996, $56,59-72$.

14. Hirschmann, W.; Wiśniewski, J. Weltweite Revision der ganggattung Trichouropoda Berlese1916. II. Die interstructura-Gruppe (Trichouropodini, Uropodinae). GDP T. 492. Acarologie 1986, 33, 81-109.

15. Hirschmann, W.; Wiśniewski, J. Weltweite Revision der ganggattung Trichouropoda Berlese1916. IV. Die longiseta-Gruppe (Trichouropodini, Uropodinae). GDP T.496. Acarologie 1987, 34, 1-50.

16. Hirschmann, W.; Wiśniewski, J. Weltweite Revision der ganggattung Trichouropoda Berlese1916 Nachträge zu den von 1986 bis 1988 revidieren Gruppen (Trichouropodini, Uropodinae). GDP T. 503. Acarologie 1988, 35, 85-115.

17. Pečina, P. Czechoslovak Uropodid mites of the Genus Trachytes Michael, 1894 (Acari: Mesostigmata). Acta Univ. Carol.-Biol. Praha 1970, 1, 39-59.

18. Trägårdh, I. Acaridienaus dem Sarekgebirge. Naturwiss. Untersuch. Sarek-Geb. Schwed. Lappland 1910, $4,375-586$.

19. Willmann, C. Milben aus Mineralquellen (2. Mitteilund). Zool. Anz. 1950, 145, 186-195.

20. Chapple, D.G.; Hoskin, C.J.; Chapple, S.N.J.; Thompson, M.B. Phylogeographic divergence in the widespread delicate skink (Lampropholis delicata) corresponds to dry habitat barriers in eastern Australia. BMC Evol. Biol. 2011, 11, 191. [CrossRef]

21. Baker, C.H.; Graham, G.C.; Scott, K.D.; Cameron, S.L.; Yeates, D.K.; Merritt, D.J. Distribution and phylogenetic relationships of Australian glow-worms Arachnocampa (Diptera, Keroplatidae). Mol. Phylogenet. Evol. 2008, 48, 506-514. [CrossRef]

22. Stansic, J. The distribution and patterns of species diversity of land snails in eastern Australia. Mem. Queensl. Mus. 1994, 36, 207-214.

23. Floyd, A.G. Rainforest Trees of Mainland South-eastern Australia. Forestry Commission of New South Wales; Inkata Press: Melbourne, Australia; Sydney, Australia, 1989; pp. 1-420. 
24. Błoszyk, J.; Halliday, R.B.; Dylewska, M.; Napierała, A. An interesting case of vicariance in the endemic mite genus Acroseius in eastern Australia (Acari: Uropodina: Trachytidae). In Integrative Acarology. Proceedings of the 6th European Congress, European Association of Acarologists; Bertrand, M., Kreiter, S., McCoy, A., Migeon, M., Navajas, M., Tixier, M.S., Vial, L., Eds.; European Association of Acarologists: Montpellier, France, 2008; pp. 44-46.

25. Hirschmann, W. Gangsystematik der Parasitiformes. Teil 536. 41 Rotundabaloghia-Arten aus Sudamerika (Venezuela, Ekuador, Peru, Bolivien, Brasilien) und Mittelamerika (Guatemala) (Dinychini, Uropodinae). Schriftenreihe für Vergleichende Milbenkunde. Acarologie 1992, 39, 69-95.

26. Hirschmann, W.; Zirngiebl-Nicol, I. Uropodiden Das Gangsystem der Fanilie Uropodide (Berlese, 1882) Hirschmann u. Zirngiebl-Nicol nov. comb. Brstimmungstabellen Kurzdiagnosen Operculumbestimmungstabellen. GDP T.7. Acarologie 1964, 6, 2-22.

27. Hirschmann, W.; Zirngiebl-Nicol, I. Uropodiden bestimmungstabellen von 300 Uropodiden-Arten (Larven, Protonymphen, Deutonymphen, Weibchen, Männchen). GDP T.9. Acarologie 1965, 8, 2-33.

28. Hirschmann, W.; Zirngiebl-Nicol, I. Neunzehn neue Uropoda-Arte. DGP T. 39. Acarologie 1969, 12, 20.

29. Hirschmann, W. Adulten-Gruppen und Bestimmungstabelle von 63 Uropoda-Arten (Uropodini, Uropodinae). GDP T. 120. Acarologie 1972, 18, 67-74.

30. Hirschmann, W. Teilgange, Stadien von 21 nneuen Uropoda (Phalodinychus)-Arten (Uropodini, Uropodinae). GDP T. 123. Acarologie 1972, 18, 79-90.

31. Hirschmann, W. Stadienfamilien und Stadiengattungender Atrichopygidiina, erstellt im Vergleich zum Gangsystem Hirschmann 1979. SDP T.1. Acarologie 1979, 26, 57-70.

32. Hirschmann, W.; Hiramatsu, N. Weibchen einer neuen Uropoda (Phaulodinychus) -Art der penicillata-Gruppe aus den Philippinen (Uropodini, Uropodinae). GDP T.517. Acarologie 1990, 37, 86-88.

33. Niedbała, W. Brachychthoniidae Polski (Acari, Oribatei): Studium Ekologiczno-Faunistyczne. Monografie Fauny Polski; Państ. Wydaw Naukowe: Warszawa, Poland; Kraków, Poland, 1976; pp. 1-144.

34. Olszanowski, Z. A Monograph of the Nothridae and Camisiidae of Poland (Acari: Oribatida: Crotonioidea); Genus (Supplement); BS: Wrocław, Poland, 1996; pp. 1-201.

35. Niedbała, W. Ptyctimous mites (Acari, Oribatida) of Poland. Fauna Poloniae. Nat. Opt. Dux. Found. 2008, 3, 1-242.

36. Błaszak, C. Zerconidae (Acari, Mesostigmata) Polski; Państwowe Wydawn. Naukowe: Kraków, Poland, 1974; pp. 1-315.

37. Błoszyk, J.; Książkiewicz-Parulska, Z.; Adamski, Z.; Napierała, A. Influence of Pleistocene glaciation on the distribution of three species of Labidostomma in Europe (Acari: Labidostommatidae). Syst. Appl. Acarol. 2017, 22, 841-857. [CrossRef]

(C) 2020 by the authors. Licensee MDPI, Basel, Switzerland. This article is an open access article distributed under the terms and conditions of the Creative Commons Attribution (CC BY) license (http://creativecommons.org/licenses/by/4.0/). 